\title{
KEPERCAYAAN TERHADAP OTORITAS PAJAK SEBAGAI PEMODERASI PENGARUH DETERRENCE FACTORS TERHADAP KEPATUHAN WAJIB PAJAK PRIBADI
}

\begin{abstract}
This study examines the role of trust to moderate the relationship between deterrence factors and taxpayer compliance behavior. Their compalince on tax regulation is hypothesized to be determined by three factors i.e. tax audit, tax fine and trust in tax authorities. Economics-of-crime approach predicts that the higher probability of tax audit and tax fine will enhance tax compliance. According to slippery slope theory, the positive relation of tax compliance and its deterrence factors might be stronger if tax payer has a higher trust in legal and taxation system. The field experiment is designed by $2 \times 2 \times 2$ between subjects. The participants comprise of 80 personal tax payers in Semarang City. Using ANOVA as statistical analysis, this reseach suggested that tax compliance is more likey to be effectively affected by trust in tax authorities rather than deterrence factor. However, according to univariate analysis, tax audit and tax fine are still important determinants of tax compliance.
\end{abstract}

Keywords: tax compliance, tax audit, tax fine, trust in tax authorities

\section{PENDAHULUAN}

Penerimaan negara dari sektor perpajakan merupakan pilar utama pendapatan dalam APBN yang digunakan untuk memenuhi kebutuhan belanja pemerintah dalam rangka pembangunan nasional. Meskipun demikian, penerimaan perpajakan masih rendah ditunjukkan dengan tax ratio Indonesia lebih rendah jika dibandingkan dengan negara-negara di kawasan Asia Tenggara, apalagi dengan Australia, seperti dalam tabel 1. Rendahnya tax ratio Indonesia sangat mengkhawatirkan karena kebutuhan belanja pemerintah justru semakin meningkat (www.tribunnews.com, 16 Oktober 2012). Oleh karena itu, Ditjen Pajak menyatakan akan melakukan inovasi kebijakan peningkatan penerimaan pajak (www.bloomberg.com, 28 Februari 2013). Inovasi kebijakan tersebut antara lain melalui peningkatan kapasitas Direktorat Jenderal (Ditjen) Pajak, menambah pegawai pajak, dan memperkuat infrastruktur perpajakan. Selain itu, Ditjen Pajak, sebagai otoritas yang berwenang, akan meningkatkan pemeriksaan secara masif terhadap wajib pajak yang diduga melanggar ketentuan perpajakan dan meningkatkan denda pajak.

Namun, kebijakan ini bertentangan dengan literatur dan hasil penelitian yang menunjukkan bahwa deterrence factors (yaitu pemeriksaan dan denda pajak) hanya akan meningkatkan kepatuhan pajak yang dipaksakan (enforced tax compliance). Dalam jangka panjang, kebijakan dengan menggunakan pemeriksaaan dan denda pajak ini akan kurang efektif karena tax ratio yang tinggi hanya dapat tercapai jika telah ada kepatuhan pajak sukarela (Kogler dkk., 2013; Kirchler dkk., 2008). Oleh karena itu, otoritas pajak seharusnya juga mempertimbangkan variabel psikologi-sosial yang cenderung dapat meningkatkan kepatuhan pajak sukarela (voluntary tax compliance).

Salah satu ciri masyarakat modern adalah mempunyai tingkat kepatuhan sukarela yang tinggi (van 
Dijke dan Verboon, 2010). Bagaimana upaya meningkatkan kepatuhan pajak sukarela ini telah menjadi ketertarikan penelitian dari berbagai multidisipilin ilmu seperti ilmu ekonomi, psikologi, dan sosiologi selama 50 tahun terakhir (Kirchler, dkk., 2008; van Dijke \& Verboon, 2010). Paradigma penelitian kepatuhan pajak pada saat ini cenderung memfokuskan pada peran variabel-variabel psikologi-sosial (Wenzel, 2004; van Dijke dan Verboon, 2010). Hal ini karena kesadaran bahwa analisis penelitian dengan menggunakan variabelvariabel deterrence saja (seperti pemeriksaan pajak dan denda pajak) tidak cukup dapat menjelaskan tingkat kepatuhan pajak. Meskipun pendekatan berbasis deterrence telah mendominasi analisis kepatuhan pajak dari perspektif ekonomika (Allingham dan Sandmo, 1972; Andreoni dkk., 1998), namun hasil penelitian-penelitian menunjukkan bahwa hanya sedikit kemampuan variabel-variabel tersebut dalam menjelaskan tingkat kepatuhan pajak.

Perkembangan teori dalam bidang kepatuhan pajak pada saat ini karenanya memandang variabelvariabel psikologi-sosial sama pentingnya dengan variabel-variabel deterrence (Kirchler, dkk. 2008). Variabel psikologi-sosial cenderung mempengaruhi kepatuhan pajak sukarela sedangkan variabel deterrence cenderung mempengaruhi kepatuhan pajak berdasar ketakutan akan konsekuensi negatif (enforced tax compliance). Kebijakan untuk meningkatkan kepatuhan pajak sukarela tergantung pada tingkat kepercayaan masyarakat pada otoritas pajak.

Cahyonowati dkk. $(2011,2012)$ memberikan bukti empiris bahwa kepatuhan wajib pajak pribadi di Indonesia masih berupa enforced tax compliance dengan denda pajak menjadi determinan utama. Namun, seperti diuraikan di atas, kebijakan peningkatan denda pajak dan pemeriksaan pajak akan kurang efektif dalam meningkatkan kepatuhan pajak sukarela (Kogler dkk., 2013; Kirchler dkk., 2008). Oleh karena itu, penelitian ini akan mengembangkan dan menguji model kepatuhan pajak dengan mengkombinasikan deterrence factors (denda dan pemeriksaan pajak) dengan variabel psikologi-sosial yaitu kepercayaan pada otoritas pajak. Variabel kepercayaan ini dihipotesiskan berperan sebagai pemoderasi karena ketidakkonsistenan hasil penelitian sebelumnya yang menguji pengaruh deterrence factors terhadap kepatuhan pajak (van Dijke dan Verboon, 2010).

\section{TINJAUAN PUSTAKA}

\section{Teori Slippery Slope}

Salah satu teori terkini tentang kepatuhan pajak adalah slippery slope model dari Kirchler dkk. (2008). Teori ini menyatakan bahwa variabel-variabel psikologi sosial dan deterrence menentukan tingkat kepatuhan pajak. Variabel psikologi-sosial cenderung mempengaruhi kepatuhan pajak sukarela (voluntary tax compliance) sedangkan variabel deterrence cenderung mempengaruhi kepatuhan pajak berdasar ketakutan akan konsekuensi negatif (kepatuhan pajak yang dipaksakan/enforced tax compliance). Teori slippery slope dapat dijelaskan seperti pada gambar 1. Kebijakan untuk meningkatkan kepatuhan pajak sukarela tergantung pada tingkat kepercayaan masyarakat pada otoritas pajak (trust in authorities). Kebijakan seperti pemeriksaan dan denda pajak cenderung akan meningkatkan persepsi terhadap kekuatan otoritas pajak (power of authorities) yang akan mempengaruhi enforced tax compliance. Kirchler dkk. (2008) menyatakan bahwa

Jurnal Akuntansi Indonesia 
terdapat kemungkinan bahwa dimensi kekuatan dan kepercayaan pada otoritas pajak saling memoderasi dalam mempengaruhi kepatuhan. Berdasar teori slippery slope ini maka kebijakan peningkatan kepercayaan masyarakat pada otoritas pajak harus diutamakan dalam rangka meningkatkan kepatuhan pajak sukarela.

\section{Hasil Penelitian Terdahulu}

Hasil penelitian menunjukkan bukti empiris yang bertentangan tentang pengaruh pemberian denda pajak terhadap tingkat kepatuhan. Terdapat beberapa penelitian yang menunjukkan bahwa pemberian sanksi dapat meningkatkan kepatuhan (misalnya hasil penelitian Eek, Loukopoulos, Fujii, dan Gärling, 2002; McCusker dan Carnevale, 1995). Namun terdapat penelitian lain yang menunjukkan pemberikan sanksi denda pajak justru menurunkan kepatuhan (misalnya hasil penelitian Mulder, Van Dijk, De Cremer, dan Wilke, 2006; van Prooijen, Gallucci, dan Toeset, 2008).

Penelitian tentang tingkat denda pajak juga penting dari perspektif teoritis karena hasil penelitian menunjukkan bukti empiris yang bertentangan. Pertanyaan mengapa tingkat denda pajak yang tinggi dapat meningkatkan kepatuhan masih menjadi isu penelitian yang penting (Verboon dan van Dijke, 2011). Terdapat dua perspekti dalam literatur keperilakuan pajak mengapa denda dan pemeriksaan pajak dapat mempengaruhi kepatuhan. Perspektif instrumental menyatakan bahwa terkadang menguntungkan untuk tidak patuh pada peraturan jika sanksi yang diberikan atas pelanggaran tersebut lebih kecil daripada keuntungan yang diperoleh dari melakukan pelanggaran. Oleh karena itu, perspektif instrumental menekankan bahwa tingkat sanksi harus lebih besar daripada keuntungan yang diperoleh dari melakukan pelangggaran (Allingham dan Sandmo, 1972; Carroll, 1978). Perspektif kedua disebut sebagai perspektif relasional yang menyatakan bahwa variabel deterrence saja (seperti denda dan pemeriksaan pajak) tidak cukup untuk menjelaskan sistem sanksi. Perspektif lebih mendasarkan pada konsep seperti keadilan prosedural, kepercayaan (trust), dan evaluasi terhadap moral otoritas pajak untuk menjelaskan mengapa denda pajak dapat meningkatkan kepatuhan. Salah satu hipotesis penting dari perspektif ini adalah pemeriksaan dan tingkat denda pajak yang lebih tinggi dapat meningkatkan kepatuhan hanya jika masyarakat mempunyai kepercayaan terhadap otoritas. Dengan kata lain, kepercayaan wajib terhadap sistem hukum dan perpajakan memoderasi pengaruh pemeriksaaan dan tingkat denda pajak terhadap kepatuhan.

\section{HIPOTESIS}

\section{Pengaruh Denda Pajak terhadap Kepatuhan dengan Kepercayaan terhadap Otoritas Pajak sebagai Variabel Pemoderasi}

Penilaian moral tentang perilaku yang pantas dihukum merupakan faktor kunci dalam memahami hubungan antara pemberian sanksi oleh otoritas pajak dan kepatuhan (Mulder, 2009). Apakah ketidakpatuhan pajak dipandang tidak bermoral atau bermoral tergantung pada bagaimana sanksi dipersepsikan: (1) sebagai compensatory yaitu menunjukkan sebuah transaksi ekonomi, atau (2) retributive menunjukkan bahwa pelanggaran norma memang layak dihukum. Sanksi yang bersifat retributive cenderung dapat meningkatkan kepatuhan dibandingkan sanksi compensatory karena menunjukkan ketidaksetujuan secara moral terhadap 
pelanggaran norma (Verboon \& van Dijke, 2011). Sanksi compensatory tidak menunjukkan pertimbangan moral karena lebih bersifat transaksi ekonomi.

Mulder (2009) menyatakan bahwa pemberian sanksi yang lebih berat cenderung dipersepsikan bersifat retributive dibandingkan sanksi ringan. Hal ini karena sanksi berat merupakan sinyal bahwa keputusan otoritas tersebut telah merepresentasikan ketidaksetujuan moral masyarakat terhadap pelanggaran pajak. Sanksi yang berat cenderung efektif dalam meningkatkan kepatuhan karena merupakan sinyal ketidaksetujuan moral terhadap pelanggaran pajak. Sanksi berupa denda pajak yang terlalu rendah dapat dipersepsikan sebagai indikator bahwa otoritas pajak lemah sehingga menurunkan kepercayaan pembayar pajak yang jujur (Kirchler dkk., 2008).

Meskipun demikian, selain hasil penelitian Mulder (2009), penelitian lainnya menunjukkan bukti empiris yang bertentangan tentang pengaruh tingkat sanksi terhadap kepatuhan (Kirchler dkk., 2008). Sebagai contoh, Tenbrunsel \& Messick (1999) menemukan bahwa pengaruh tingkat sanksi terhadap kepatuhan tergantung (dimoderasi) oleh probabilitas persepsian bahwa pelaku akan tertangkap melakukan pelanggaran oleh otoritas. Mulder (2009) menemukan tingkat sanksi dapat meningkatkan moral concerns tentang perilaku yang tidak etis jika otoritas diperspsikan dapat dipercaya. Wenzel (2004) menemukan bahwa tingkat sanksi berpengaruh terhadap kepatuhan untuk masyarakat yang percaya bahwa membayar pajak merupakan sebuah perilaku etis. Verboon dan van Dijke (2011) menemukan bahwa tingkat sanksi yang lebih berat dapat meningkatkan kepatuhan hanya jika prosedur pemberikan sanksi tersebut dipandang fair oleh masyarakat. Dengan kata lain, pemberian sanksi yang berat melalui prosedur yang adil dapat meningkatkan kepatuhan perpajakan.

Ketidakkkonsistenan hasil penelitian di atas menunjukkan bahwa pengaruh tingkat denda pajak terhadap kepatuhan tergantung pada (dimoderasi oleh) variabel lain. Tyler (2006) menyatakan bahwa pengaruh sanksi yang berat dalam meningkatkan kepatuhan pajak tergantung pada apakah otoritas pajak dipersepsikan mempunyai legitimasi dengan telah melakukan prosedur yang tepat, benar, dan adil (Tyler, 2006). Kirchler dkk. (2008) menyatakan pendapat serupa yaitu bahwa pemberian denda pajak yang tidak tepat misalnya dalam kasus seorang pembayar pajak secara tidak sengaja membuat kesalahan karena tidak jelasnya peraturan pajak dapat menurunkan kepercayaan masyarakat pada otoritas pajak.

Sejalan dengan pendapat di atas, Verboon dan van Dijke (2011) menyatakan bahwa tingkat sanksi pajak yang tinggi dapat meningkatkan kepatuhan hanya jika prosedur pemberian sanksi tersebut dipandang adil. Tingkat keadilan prosedural merupakan salah sumber penting bagi masyarakat dalam mengevaluasi tingkat moral otoritas pajak. Hasil penelitian menunjukkan temuan yang konsisten bahwa masyarakat mempersepsikan otoritas yang memberikan sanksi dengan prosedur yang tidak fair sebagai otoritas yang tidak mempunyai legitimasi (Murphy, 2004; Tyler, 1997, 2006). Selain itu, hasil penelitian van Prooijen dkk. (2008) menunjukkan bahwa sistem sanksi hanya efektif dalam meningkatkan kepatuhan jika prosedur pemberikan sanksi tersebut dinilai adil. Persepsi terhadap ketidakadilan prosedural tersebut dapat menyebabkan kepercayaan (trust) terhadap otoritas menjadi menurun. Ketika otoritas pajak telah membuat prosedur secara fair, termasuk dalam pemberian sanksi denda pajak yang tinggi, masyarakat akan cenderung taat pada keputusan otoritas tersebut (Cropanzano, Rupp, Mohler, dan Schminke, 2001; de Cremer dan Tyler, 2005; Tyler, 2006).

Jurnal Akuntansi Indonesia 
Dengan mengacu pada teori slippery slope dan hasil studi terdahulu maka dapat dinyatakan bahwa denda pajak yang tinggi dapat meningkatkan kepatuhan perpajakan hanya jika masyarakat percaya bahwa otoritas pajak telah bertindak secara benar dan adil. Secara formal argumen tersebut dinyatakan dalam hipotesis pertama berikut ini:

H1: Semakin tinggi denda pajak dan semakin besar kepercayaan terhadap sistem hukum dan perpajakan maka semakin besar tingkat kepatuhan wajib pajak.

\section{Pengaruh Probabilitas Pemeriksaan Pajak terhadap Kepatuhan dengan Kepercayaan Otoritas Pajak sebagai Variabel Pemoderasi}

Pemeriksaan pajak diyakini merupakan salah satu upaya untuk mengkonfirmasi kepatuhan pajak seseorang baik secara formil maupun secara materiil. Pendekatan economics-of-crime memprediksi bahwa probabilitas wajib pajak melakukan tax evasion semakin berkurang seiring dengan meningkatnya probabilitas wajib pajak untuk diperiksa (Togler dan Schneider, 2004). Mekanisme pemeriksaan pajak mungkin akan cukup efektif untuk meningkatkan kepatuhan perpajakan jika wajib pajak berpersepsi bahwa sistem hukum dan peraturan perpajakan telah dijalankan secara benar. Togler dan Schneider (2004) menyatakan bahwa motivasi intrinsik untuk membayar pajak di Austria ditentukan oleh tingkat kepercayaan warga negara pada sistem hukum.

Beberapa hasil penelitian terdahulu menunjukkan bahwa pemeriksaan pajak saja tidak cukup untuk meningkatkan kepatuhan. Frey dan Feld (2002) menunjukkan bahwa kemungkinan adanya pemeriksaan pajak tidak dapat menurunkan tax evasion. Beron, Tauchen dan Witte (1992) juga menunjukkan pemeriksaan pajak belum cukup untuk meningkatkan kepatuhan perpajakan. Torgler (2002) menunjukkan bahwa pemeriksaan pajak (tax audit) berhubungan positif dengan tingginya tax morale. Selanjutnya, Torgler dan Schneider (2004) memprediksi bahwa tax morale merupakan determinan kunci yang menyebabkan seseorang berperilaku jujur. Seseorang yang berperilaku jujur maka tidak melakukan tax evasion. Sebaliknya, Cahyonowati dkk. (2011) menunjukkan bahwa pemeriksaan pajak tidak berhubungan positif dengan tax morale. Seperti yang dijelaskan oleh teori slippery slope, pemeriksaan pajak hanya akan meningkatkan enforced tax compliance. Dalam rangka meningkatkan kepatuhan perpajakan secara keseluruhan, pemeriksaan pajak harus didukung adanya kepercayaan terhadap sistem hukum dan perpajakan. Oleh karena itu dapat diajukan argumentasi bahwa besarnya kepercayaan pada otoritas pajak dapat meningkatkan pengaruh pemeriksaan pajak terhadap kepatuhan wajib pajak pribadi.

H2: Semakin kemungkinan pemeriksaan pajak dan semakin besar kepercayaan terhadap sistem hukum dan perpajakan maka semakin besar tingkat kepatuhan wajib pajak.

\section{METODA PENELITIAN}

\section{Desain dan Partisipan Eksperimen}

Terdapat tiga variabel yang diuji dalam eksperimen yaitu kepercayaan terhadap sistem hukum dan perpajakan, probabilitas pemeriksaan pajak, dan tingkat denda pajak. Desain eksperimen yang digunakan adalah $2 \times 2 \times 2$ 
between subject dengan manipulasi variabel: (1) Kepercayaan terhadap otoritas pajak (rendah dan tinggi), (2) Probabilitas pemeriksaan pajak (rendah dan tinggi), dan (3) denda pajak (rendah dan tinggi). Tabel 1 menyajikan desain eksperimen yang digunakan dalam penelitian ini. Secara keseluruhan terdapat 8 sel eksperimen yang digunakan untuk memanipulasi 3 variabel penelitian. Sebagai partisipan eksperimen adalah 80 wajib pajak pribadi di kota Semarang. Terdapat 10 orang partisipan untuk masing-masing sel.

\section{Definisi dan manipulasi variabel}

Variabel dependen adalah tingkat kepatuhan perpajakan, yaitu keputusan wajib pajak orang pribadi untuk mematuhi peraturan perpajakan. Pengukuran tingkat kepatuhan pajak menggunakan skenario tentang situasi di mana responden harus menyatakan pilihan tingkat kepatuhan pada situasi tertentu seperti diadaptasi dari instrumen Verboon dan van Dijke (2011).Variabel independen yang dimanipulasi dalam eksperimen adalah:

1) Probabilitas Pemeriksaan pajak

Probabilitas pemeriksaan pajak dimanipulasi menjadi 2 kategori yaitu probabilitas pemeriksaan pajak rendah (sel A, B, E, dan F) dan probabilitas pemeriksaan pajak tinggi (sel C, D, G, dan H). Dalam sel A, B, E dan F, partisipan diberikan informasi bahwa data-data yang mereka laporkan dalam SPT kemungkinan tidak akan diperiksa kebenarannya oleh Kantor Pelayanan Pajak (KPP) setempat. Sedangkan dalam C, D, G, dan $\mathrm{H}$, partisipan akan diberikan informasi bahwa data-data yang mereka laporkan dalam SPT kemungkinan besar akan diperiksa kebenarannya oleh Kantor Pelayanan Pajak (KPP) setempat.

2) Denda pajak

Variabel ini dimanipulasi pada dua level yaitu denda pajak tinggi dan rendah. Dalam sel B, D, F dan $\mathrm{H}$, partisipan diberikan informasi bahwa jika wajib pajak pribadi dengan sengaja tidak melaporkan secara benar data penghasilan dalam SPT maka ia akan dikenakan denda sebesar 50\% dari penghasilan yang tidak dilaporkan tersebut. Sedangkan dalam A, C, E, dan G, partisipan akan diberikan informasi bahwa jika wajib pajak pribadi dengan sengaja tidak melaporkan secara benar data penghasilan dalam SPT maka ia hanya akan dikenakan denda sebesar $1 \%$ dari penghasilan yang tidak dilaporkan tersebut.

3) Kepercayaan terhadap otoritas pajak

Variabel ini dimanipulasi pada 2 level yaitu tinggi dan rendah. Dalam sel A, B, C, dan D partisipan diberikan informasi bahwa sistem hukum dan perpajakan yang telah diaturkan oleh negara tidak dijalankan dengan baik dan bersih oleh aparat, terjadi banyak kasus penggelapan pajak dan korupsi oleh aparatur perpajakan. Dalam sela E, F, G, dan H partisipan diberikan informasi bahwa negara beserta aparatnya menjalankan sistem hukum dan perpajakan yang bersih dan bebas korupsi.

\section{Pengujian hipotesis}

Alat analisis yang digunakan adalah Analysis of Variance (ANOVA) karena variabel terikat (yaitu tingkat kepatuhan perpajakan) akan diukur dengan skala rasio sedangkan variabel bebas (yaitu variabel-variabel yang dapat dimanipulasi) diukur dengan skala nominal (Hair, dkk., 2010). 


\section{HASIL}

\section{Statistik Deskriptif dan Analisis Univariat}

Tabel 3 menyajikan statistik deskriptif untuk variabel probabilitas pemeriksaan perpajakan. Jika kemungkinan besar wajib pajak akan diaudit oleh aparat pajak (probabilitas pemeriksaan pajak tinggi), subyek eksperimen mempunyai rata-rata tingkat kepatuhan perpajakan yang lebih tinggi $(68,75)$ dibandingkan jika kemungkinan kecil akan diaudit $(60,75)$.

Hasil plots ANOVA dalam Gambar 3 menunjukkan adanya hubungan positif antara variabel probabilitas pemeriksaaan pajak dan tingkat kepatuhan perpajakan. Sesuai dengan teori ekonomi, semakin tinggi wajib pajak akan diperiksa maka semakin tinggi tingkat kepatuhan mereka.

Tabel 4 menyajikan statistik deskriptif untuk variabel tingkat denda pajak. Jika kemungkinan besar wajib pajak dikenakan denda yang tinggi atas pelanggaran pajak, subyek eksperimen mempunyai rata-rata tingkat kepatuhan perpajakan yang lebih tinggi $(70,75)$ dibandingkan jika kemungkinan mendapat denda yang lebih rendah $(58,75)$.

Hasil plots ANOVA dalam Gambar 4 menunjukkan bahwa semakin tinggi tingkat denda yang akan dikenakan maka semakin tinggi tingkat kepatuhan wajib pajak.

Tabel 5 menyajikan statistik deskriptif untuk variabel kepercayaan terhadap otoritas pajak/sistem hukum dan perpajakan. Dalam kondisi kepercayaan terhadap sistem hukum dan perpajakan yang tinggi, subyek eksperimen mempunyai rata-rata tingkat kepatuhan perpajakan yang lebih tinggi $(78,75)$ dibandingkan dalam kondisi kepercayaan terhadap sistem hukum dan perpajakan yang rendah $(50,75)$.

Hasil plots ANOVA dalam Gambar 5 menunjukkan bahwa variabel kepercayaan terhadap sistem hukum dan perpajakan berpengaruh positif pada tingkat kepatuhan perpajakan. Semakin tinggi kepercayaan masyarakat terhadap sistem hukum dan perpajakan maka semakin tinggi tingkat kepatuhan mereka.

\section{HASIL PENGUJIAN HIPOTESIS}

\section{Hasil Pengujian Hipotesis Pertama}

Tabel 6 berikut menyajikan hasil pengujian hipotesis kedua dengan ANOVA. Hasil pengujian menunjukkan bahwa efek utama (main effect) variabel denda dan kepercayaan terhadap otoritas pajak berpengaruh signifikan secara statistis. Namun efek interaksi kedua variabel tersebut (percaya*denda) tidak signifikan dengan nilai $p$ sebesar 0,335.

Tabel berikut menyajikan statistik deksriptif dan pengujian multiple comparisons masing-masing kondisi/ sel eksperimen. Tingkat kepatuhan tertinggi adalah pada kondisi kepercayaan terhadap otoritas pajak tinggi dan denda pajak tinggi (sel 4) dengan rata-rata kepatuhan sebesar 83,75. Hasil pengujian multiple comparisons dengan LSD, Bonferroni, dan Tukey HSD menunjukkan perbedaan rata-rata sel 4 adalah signifikan lebih tinggi ketiga sel lainnya. Hasil ini menunjukkan bahwa dukungan terhadap hipotesis pertama.

Gambar 6 menyajikan hasil profile plots ANOVA untuk interaksi variabel kepercayaan terhadap otoritas pajak dengan denda pajak pajak. Hasilnya menunjukkan bahwa kepercayaan terhadap otoritas pajak dapat 
meningkatkan kepatuhan wajib pajak secara signifikan dalam kondisi tingkat denda pajak rendah dan tinggi. Secara keseluruhan, hasil pengujian menunjukkan dukungan terhadap hipotesis pertama yaitu semakin tinggi denda pajak dan semakin besar kepercayaan terhadap sistem hukum dan perpajakan maka semakin besar tingkat kepatuhan wajib pajak.

\section{Hasil Pengujian Hipotesis Kedua}

Tabel 8 menyajikan hasil pengujian hipotesis kedua dengan ANOVA. Nampak bahwa efek utama (main effect) variabel pemeriksaan pajak dan kepercayaan terhadap otoritas pajak berpengaruh signifikan secara statistis. Namun efek interaksi kedua variabel tersebut (periksa*percaya) tidak signifikan dengan nilai p sebesar 0,280. Hal ini mengindikasikan tidak didukungnya hipotesis kedua.

Tabel berikut menyajikan statistik deksriptif masing-masing kondisi/sel eksperimen. Tingkat kepatuhan tertinggi adalah pada kondisi kepercayaan terhadap otoritas pajak tinggi dan probabilitas pemeriksaan pajak tinggi (sel 4) dengan rata-rata kepatuhan sebesar 81,50. Hasil pengujian multiple comparisons dengan LSD, Bonferroni, dan Tukey HSD menunjukkan perbedaan rata-rata sel 4 adalah signifikan lebih tinggi dengan sel 1 dan 2. Namun perbedaan ini tidak signifikan secara statistis dengan kondisi kepercayaan tinggi dan pemeriksaan rendah (sel 3). Hasil ini menunjukkan bahwa hipotesis kedua tidak didukung. Hasil pengujian ini menunjukkan bahwa faktor utama yang dapat meningkatkan kepatuhan perpajakan secara signifikan adalah variabel kepercayaan terhadap otoritas pajak ( $F=148,774)$ dibandingkan variabel pemeriksaan pajak $(\mathrm{F}=12,145)$.

Gambar 7 menyajikan hasil profile plots ANOVA untuk interaksi variabel kepercayaan terhadap otoritas pajak dengan variabel probabilitas pemeriksaan pajak. Hasilnya menunjukkan bahwa kepercayaan terhadap otoritas pajak dapat meningkatkan kepatuhan dalam kondisi pemeriksaan pajak rendah dan tinggi. Secara keseluruhan, hasil pengujian menunjukkan pentingnya variabel kepercayaan terhadap otoritas pajak.

\section{Pembahasan Hasil Penelitian}

Hasil penelitian ini menunjukkan bahwa kepatuhan perpajakan wajib pajak pribadi di Kota Semarang masih ditentukan oleh variabel ekonomi seperti kemungkinan pemeriksaan pajak dan denda pajak. Wajib pajak cenderung mempunyai tingkat kepatuhan yang tinggi jika kemungkinan besar mereka akan diperiksa/diaudit oleh aparat pajak dan dikenakan denda yang tinggi atas pelanggaran pajak. Namun, variabel kepercayaan terhadap otoritas perajan lebih mempengaruhi tingkat kepatuhan perpajakan dibandingkan variabel pemeriksaan dan denda pajak. Oleh karena itu, dalam jangka panjang, sangat penting bagi pemerintah untuk meningkatkan kepercayaan masyarakat terhadap sistem hukum dan perpajakan karena variabel ini dapat meningkatkan motivasi intrinsik untuk taat terhadap peraturan perpajakan. Pentingnya variabel kepercayaan terhadap otoritas pajak juga menunjukkan dukungan teori slippery slope bahwa dimensi trust in authorities berperan penting dalam meningkatkan voluntary tax compliance (Kirchler dkk., 2008)

Hasil penelitian ini menunjukkan bahwa kepercayaan terhadap otoritas pajak merupakan faktor penting 
yang harus diperhatikan pemerintah karena secara langsung maupun tidak langsung dapat meningkatkan kepatuhan perpajakan wajib pajak orang pribadi. Sedangkan deterrence factors berupa pemeriksaan pajak dan denda pajak dalam jangka pendek diperlukan untuk meningkatkan kepatuhan. Hal ini sesuai dengan teori ekonomi, bahwa individu mempertimbangkan biaya oportunitas (opportunistic cost) dalam keputusan untuk patuh atau tidak patuh pada peraturan peraturan perpajakan. Hasil penelitian ini mendukung penelitian sebelumnya bahwa kepatuhan wajib pajak di Indonesia adalah kepatuhan yang dipaksakan (enforced tax compliance) yang disebabkan oleh adanya kemungkinan pemeriksaan pajak dan ancaman denda yang tinggi (Cahyonowati, 2011). Tingkat denda pajak menjadi semakin efektif pada kondisi wajib pajak percaya terhadap sistem hukum dan perpajakan yang dijalankan secara benar dan bersih oleh aparat.

\section{KESIMPULAN, KETERBATASAN, DAN SARAN PENELITIAN MENDATANG}

Penelitian ini menunjukkan dukungan terhadap teori slippery slope bahwa kepercayaan terhadap sistem hukum dan perpajakan lebih menentukan kepatuhan perpajakan wajib pajak orang pribadi dibandingkan pemeriksaan dan denda pajak. Pemeriksaan pajak dan denda pajak dalam jangka pendek tetap diperlukan untuk meningkatkan kepatuhan wajib pajak pribadi. Oleh karena itu, dalam jangka panjang penting bagi Pemerintah untuk meningkatkan kepercayaan terhadap sistem hukum dan perpajakan sehingga wajib pajak akan mematuhi peraturan perpajakan secara sukarela (voluntary tax compliance).

Terdapat beberapa keterbatasan penelitian ini yang dapat menjadi saran bagi penelitian mendatang. Pertama, penelitian ini menggunakan disain eksperimen yang mempunyai kelebihan dalam validitas internal namun terbatas dalam validitas eksternal. Penggunaan disain penelitian seperti survei kuesioner pada penelitian mendatang dapat menguji generalisasi temuan penelitian ini. Kedua, disain eksperimen dalam penelitian ini juga mempunyai keterbatasan yaitu tidak semua informasi yang relevan dalam pengambilan keputusan diberikan kepada subjek. Penelitian juga dapat menguji peran variabel-variabel lain seperti yang telah diidentifikasi dalam teori slippery slope seperti keadilan prosedural, tarif pajak, tingkat pengetahuan perpajakan, dan sikap terhadap pajak (Kircler dkk., 2008).

\section{DAFTAR PUSTAKA}

Allingham, M.G. dan Sandmo, A. 1972. Income Tax Evasion: A Theoretical Analysis. Journal of Public Economics 1(3) hal 323-338

Alm, J. 1991. A Perspective on the Experimental Analysis of Taxpayer Reporting. The Accounting Review 66 (July) hal 577-593

Alm, J., Jackson, B. R., \& McKee, M. 1993. Fiscal exchange, collective decisions institutions, and tax compliance. Journal of Economic Behavior and Organization, 22, 285-303.

Andreoni, J., Erard, B., \& Feinstein, J. 1998. Tax compliance. Journal of Economic Literature, 36, 818-860.

Cahyonowati, Nur., Kiswara, E dan Ratmono, D. 2011. Model Moral dan Kepatuhan Perpajakan Wajib Pajak Orang Pribadi. Laporan Hibah Bersaing tahun I.

KEPERCAYAAN TERHADAP OTORITAS PAJAK 
Cahyonowati, Nur., Kiswara, E dan Ratmono, D. 2012. Model Moral dan Kepatuhan Perpajakan Wajib Pajak Orang Pribadi. Laporan Hibah Bersaing tahun II.

Carroll, J. S. 1978. A psychological approach to deterrence: The evaluation of crime opportunities. Journal of Personality and Social Psychology, 36, 1512-1520.

Cropanzano, R., Rupp, D. E., Mohler, C., \& Schminke, M. 2001. Three roads to organizational justice. Research in Personnel and Human Resources Management, 20, 1-113.

De Cremer, D., \& Tyler, T. R. 2005. Managing group behavior: The interplay between procedural justice, sense of self, and cooperation. In M. P. Zanna (Ed.). Advances in experimental social psychology (Vol. 37, pp. 151-218). San Diego, CA: Elsevier Academic Press.

Eek, D., Loukopoulos, P., Fujii, S., \& Gärling, T. 2002. Spill-over effects of intermittent costs for defection in social dilemmas. European Journal of Social Psychology, 32, 801-813.

Hair, J., W. Black, B. Babin, dan R. Anderson. 2010. Multivariate Data Analysis: A Global Perspective (7th edition). New Jersey: Pearson.

Kirchler, E., Hoelzl, E \& Wahl, I. 2008. Enforced versus voluntary tax compliance: The "slippery slope" framework. Journal of Economic Psychology 29 hal 210-225

Kogler, C, Batrancea L \& Nichita A. 2013. Trust and power as determinants of tax compliance: Testing the assumptions of the slippery slope framework in Austria, Hungary, Romania and Russia. Journal of Economic Psychology 34 hal 169-180.

Korsgaard, M. A., Schweiger, D. M., \& Sapienza, H. J. 1995. Building commitment, attachment, and trust in strategic decision-making teams: The role of procedural justice. Academy of Management Journal, 38, 60-84.

Mulder, L. B., Van Dijk, E., De Cremer, D., \& Wilke, H. A. M. 2006. Undermining trust and cooperation:The paradox of sanctioning systems in social dilemmas. Journal of Experimental Social Psychology, 42, 147-162.

Mulder, L. B., Verboon, P., \& De Cremer, D. 2009. Sanctions and moral judgments: The moderating effect of sanction severity and trust in authorities. European Journal of Social Psychology, 39, 255-269.

Murphy, K. 2004. The role of trust in nurturing compliance: A study of accused tax avoiders. Law and Human Behavior, 28, 187-209.

Murphy, K., \& Tyler, T. 2008. Procedural justice and compliance behaviour: The mediating role of emotions. European Journal of Social Psychology, 38, 652-668.

Porcano, T. M. 1988. Correlates of tax evasion. Journal of Economic Psychology, 9, 47-67.

Stalans, L., \& Lind, E. A. 1997. The meaning of procedural fairness: A comparison of taxpayers'and representatives' views of their procedural fairness. Social Justice Research, 10, 311-331.

Tenbrunsel, A. E., \& Messick, D. M. 1999. Sanctioning systems, decision frames, and cooperation. Administrative Science Quarterly, 44, 684-707.

Tyler, T. R. 1997. The psychology of legitimacy. A relational perspective on voluntary deference to authorities. Personality and Social Psychology Review, 1, 323-345.

Tyler, T. R. 2006. Psychological perspectives on legitimacy and legitimation. Annual Review of Psychology, 57, 
375-400.

van Dijke, M dan Verboon, P. 2010. Trust in authorities as a boundary condition to procedural fairness effects on tax compliance. Journal of Economic Psychology 31 hal 80-91

van Prooijen, J.-W., Gallucci, M., \& Toeset, G. 2008. Procedural justice in punishment systems: Inconsistent punishment procedures have detrimental effects on cooperation. British Journal of Social Psychology, 47, 311-324.

Verboon, P dan van Dijke, M. 2011. When do severe sanctions enhance compliance? The role of procedural fairness. Journal of Economic Psychology 32 hal 120-130

Wenzel, M. 2004. The social side of sanctions: Personal and social norms as moderators of deterrence. Law and Human Behavior, 28, 547-567.

Worsham, R. G. Jr., 1996. The effect of tax authority behavior on tax payer compliance: A procedural justice approach. Journal of the American Taxation Association, 18, 19-39. 
Lampiran

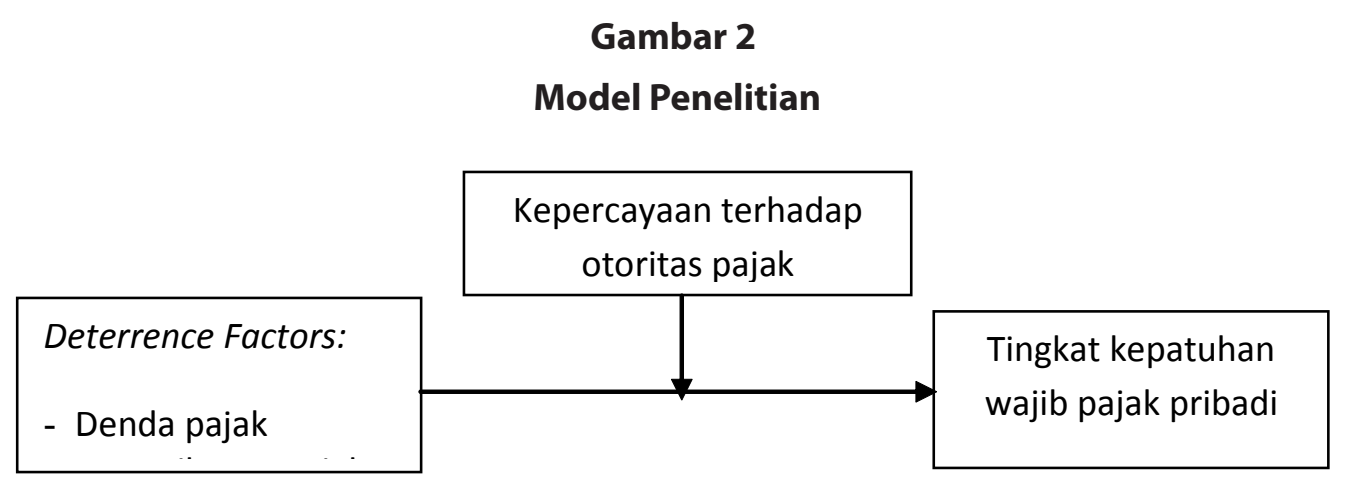

Tabel 1

Tax Ratio Indonesia dan Negara Asia Tenggara dan Australia (dalam \%)

\begin{tabular}{lcccc}
\hline \multirow{2}{*}{ Negara } & \multicolumn{5}{c}{ Tahun } \\
\cline { 2 - 5 } & $\mathbf{2 0 0 8}$ & $\mathbf{2 0 0 9}$ & $\mathbf{2 0 1 0}$ & $\mathbf{2 0 1 1}$ \\
\hline Indonesia & 13,00 & 11,40 & 10,90 & 11,90 \\
\hline Malaysia & 14,70 & 14,90 & 13,80 & n.a. \\
\hline Filipina & 13,60 & 12,20 & 12,10 & 12,30 \\
\hline Thailand & 16,40 & 15,20 & 16,00 & 17,60 \\
\hline Singapura & 15,00 & 14,70 & 13,50 & 14,10 \\
\hline Australia & 24,30 & 22,20 & 20,70 & 20,60 \\
\hline
\end{tabular}

Sumber: www. data.worldbank.org

Tabel 2

Desain Eksperimen

Kepercayaan terhadap otoritas pajak: rendah (1)

\begin{tabular}{ccc}
\hline $\begin{array}{c}\text { Denda } \\
\text { Pajak }\end{array}$ & \multicolumn{2}{c}{ Probabilitas Pemeriksaan Pajak } \\
\cline { 2 - 3 } & Rendah (1) & Tinggi $(2)$ \\
\hline Rendah (1\%)( 1) & $\mathrm{A}(1,1,1)$ & $\mathrm{C}(1,2,1)$ \\
\hline \multicolumn{2}{c}{ Kepercayaan terhadap otoritas pajak: tinggi $(2)$} \\
\hline Denda & $\mathrm{B}(1,1,2)$ & Probabilitas Pemeriksaan Pajak \\
\hline Pajak & Rendah (1) & Tinggi $(2)$ \\
\hline Rendah (1\%) (1) & $\mathrm{E}(2,1,1)$ & $\mathrm{G}(2,2,1)$ \\
\hline Tinggi (50\%) (2) & $\mathrm{F}(2,1,2)$ & $\mathrm{H}(2,2,2)$ \\
\hline
\end{tabular}


Tabel 3

Statistik Deskriptif Variabel Probabilitas Pemeriksaan Perpajakan

Descriptive Statistics

\begin{tabular}{llll}
\hline \hline & & & \\
\hline rendah & 60,75 & 18,795 & 40 \\
tinggi & 68,75 & 16,043 & 40 \\
Total & 64,75 & 17,823 & 80 \\
\hline \hline
\end{tabular}

Tabel 4

Statistik Deskriptif Variabel Tingkat Denda Pajak

Descriptive Statistics

\begin{tabular}{llll}
\hline \hline & & & \\
\hline rendah & 58,75 & 18,001 & 40 \\
tinggi & 70,75 & 15,671 & 40 \\
Total & 64,75 & 17,823 & 80 \\
\hline \hline
\end{tabular}

Tabel 5

Statistik Deskriptif Kepercayaan terhadap Otoritas Pajak

Descriptive Statistics

\begin{tabular}{lrrr}
\hline \hline & & & \\
\hline rendah & 50,75 & 12,171 & 40 \\
tinggi & 78,75 & 9,658 & 40 \\
Total & 64,75 & 17,823 & 80 \\
\hline \hline
\end{tabular}


Tabel 6

Hasil Pengujian ANOVA

Tests of Between-Subjects Effects

\begin{tabular}{lcrrrrr}
\hline Dependent Variable:tingkat kepatuhan perpajakan & & & \\
\hline \hline Source & $\begin{array}{c}\text { Type III Sum of } \\
\text { Squares }\end{array}$ & Df & & Mean Square & \multicolumn{1}{c}{ F } & \multicolumn{1}{c}{ Sig. } \\
\hline Corrected Model & $18640.000^{\mathrm{a}}$ & 3 & 6213.333 & 73.155 & .000 \\
\hline Intercept & 335405.000 & 1 & 335405.000 & $3.949 \mathrm{E} 3$ & .000 \\
\hline percaya & 15680.000 & 1 & 15680.000 & 184.613 & .000 \\
\hline denda & 2880.000 & 1 & 2880.000 & 33.909 & .000 \\
\hline percaya * denda & 80.000 & 1 & 80.000 & .942 & .335 \\
\hline Error & 6455.000 & 76 & 84.934 & & \\
\hline Total & 360500.000 & 80 & & & \\
\hline Corrected Total & 25095.000 & 79 & & & \\
\hline
\end{tabular}

a. R Squared $=.743$ (Adjusted R Squared $=.733$ )

Tabel 7

Statistik Deskriptif dan Hasil Pengujian Multiple Comparisons

\begin{tabular}{llrr}
\hline \multicolumn{1}{c}{ Kondisi Eksperimental } & N & Rata-rata & Deviasi Standar \\
\hline percaya rendah denda rendah (1) & 20 & 43.75 & 12.017 \\
\hline percaya rendah denda tinggi (2) & 20 & 57.75 & 7.518 \\
\hline percaya tinggi denda rendah (3) & 20 & 73.75 & 6.859 \\
\hline percaya tinggi denda tinggi (4)*** & 20 & 83.75 & 9.580 \\
\hline Total & 80 & 64.75 & 17.823 \\
\hline *** berbeda signifikan pada 0,05 dengan rata-rata kondisi lain menurut hasil pengujian multiple comparisons \\
dengan metode LSD, Bonferroni, dan Tukey HSD
\end{tabular}

Tabel 8

Hasil Pengujian ANOVA

Tests of Between-Subjects Effects

\begin{tabular}{lrrrrr}
\hline Dependent Variable:tingkat kepatuhan perpajakan & & & \\
\hline \hline Source & Type III Sum of & Df & Mean Square & \multicolumn{1}{c}{ F } & \multicolumn{1}{l}{ Sig. } \\
\hline Corrected Model & $17085.000^{\mathrm{a}}$ & 3 & 5695.000 & 54.035 & .000 \\
\hline Intercept & 335405.000 & 1 & 335405.000 & $3.182 \mathrm{E} 3$ & .000 \\
\hline Periksa & 1280.000 & 1 & 1280.000 & 12.145 & .001 \\
\hline Percaya & 15680.000 & 1 & 15680.000 & 148.774 & .000 \\
\hline periksa * percaya & 125.000 & 1 & 125.000 & 1.186 & .280 \\
\hline Error & 8010.000 & 76 & 105.395 & & \\
\hline Total & 360500.000 & 80 & & & \\
\hline Corrected Total & 25095.000 & 79 & & & \\
\hline \hline
\end{tabular}

a. R Squared $=.681$ (Adjusted R Squared $=.668$ ) 
Tabel 9

Statistik Deskriptif dan Hasil Pengujian Multiple Comparisons

\begin{tabular}{lrrr}
\hline \multicolumn{1}{c}{ Kondisi Eksperimental } & N & $\begin{array}{c}\text { Rata-rata } \\
\text { Kepatuhan }\end{array}$ & \multicolumn{1}{c}{$\begin{array}{c}\text { Deviasi } \\
\text { Standar }\end{array}$} \\
\hline percaya rendah pemeriksaan rendah (1) & 20 & 45.50 & 12.866 \\
\hline percaya rendah pemeriksaan tinggi (2) & 20 & 56.00 & 8.974 \\
\hline percaya tinggi periksa rendah (3) & 20 & 76.00 & 8.367 \\
\hline percaya tinggi periksa tinggi (4) & 20 & 81.50 & 10.273 \\
\hline Total & 80 & 64.75 & 17.823 \\
\hline \hline
\end{tabular}


